\title{
Proceeding
}

Supplementary Issue: Spring Conferences of Sports Science. Costa Blanca Sports Science Week, 26-28 April 2018. Calpe. Alicante, Spain

\section{Photography and sport: Study of the didactic value of reference images in photojournalism, analysis of the winning photos of the World Press Photo in 2017}

RAFAEL MARFIL-CARMONA $\triangle$, PILAR PUERTAS-MOLERO, FÉLIX ZURITA-ORTEGA, GABRIEL GONZÁLEZ-VALERO

Department of Didactics of Musical, Plastic and Corporal Expression, University of Granada, Spain

\begin{abstract}
The media offer, on a daily basis, an idea of sport that influences citizenship's understanding of physical activity. In the case of photography, the visual narrative that appears in the press has a great aesthetic beauty and a show character, focusing mostly on the professional and competitive dimension. This research studies the winning photographs in the World Press Photo photojournalism contest, the most prestigious international photojournalism competition. In particular, the winning works of the 2017 edition were analysed from the perspective of content analysis, with a particular focus on formal and compositional aspects, including photographic technique, as well as the didactic values contained in these images. One of the most important conclusions of this research is the epic and elite-focused dimension of the activity in the most influential photos published in the press. The message of these images associates sport with the professional elite and not with everyday activity or healthy lifestyle habits. Key words: SPORTS, PHYSICAL EDUCATION, PHOTOJOURNALISM, WORLD PRESS PHOTO, CONTENT ANALYSIS.
\end{abstract}

\section{Cite this article as:}

Marfil-Carmona, R., Puertas-Molero, P., Zurita-Ortega, F., \& González-Valero, G. (2018). Photography and sport: Study of the didactic value of reference images in photojournalism, analysis of the winning photos of the World Press Photo in 2017. Journal of Human Sport and Exercise, 13(2proc), S541S553. doi:https://doi.org/10.14198/jhse.2018.13.Proc2.37

Corresponding author. Department of Didactics of Musical, Plastic and Corporal Expression, University of Granada, Spain. E-mail: rmarfil@ugr.es

Supplementary Issue: Spring Conferences of Sports Science. Costa Blanca Sports Science Week, 26-28 April 2018. Calpe. Alicante, Spain.

JOURNAL OF HUMAN SPORT \& EXERCISE ISSN 1988-5202

(c) Faculty of Education. University of Alicante

doi: 10.14198/jhse.2018.13.Proc2.37 


\section{INTRODUCTION}

Sport is, in itself, a very useful tool for learning many essential things. It is a metaphor for the vital struggle, internal and external, individual and collective. It is based not only on effort, but also on strategic capability and social intelligence. Moreover, since its professionalization in the 20th century, sports activity has incorporated the logic of the market and leadership. As Roland Barthes said in the 1950s, "Sport can illustrate all the moral values of endurance, cold blood, temerity and courage. Great players are not stars, they are heroes" (2008, p.63). This observation, made from the perspective of semiotics and the analysis of contemporary culture, becomes much more evident in the 21st century. Today, marketing has consolidated and standardized the processes that make great teams and athletes a reference for mass audiences.

There is a commercial perspective of the professionalization of sport, which is absolutely integrated in these promotional processes. Together with this commercial vision, journalistic information is the great instrument that helps citizens to understand their immediate context, but also to know what is happening in other parts of the world. Sport has great social relevance. It is one of the main thematic focuses of the media. Its educational impact is unquestionable. Thus, the influence of this constant flow of information has a didactic effect and impact. The contents of the media influence the idea we have of physical activity in general and of organised sport in particular. In these contents you can find all the positive values, typical of physical effort, health, personal improvement or teamwork, but also the commercialization processes with that which identifies us with the most essential of the human condition.

In addition, the massive diffusion of sport as a way to socialize and as a meeting place between different countries and cultures has generated a boom in specialized information. Specialization is, without a doubt, a facet of great interest in journalism (Llano, 2008; Martínez Rodríguez \& Parra Pujante, 2010). In addition to this trend, the reader is becoming more and more demanding. He is increasingly trained and interested in analysis, contextualization and depth (Herrero Aguado, 2013, p.16). This is true in all areas, without distinction.

Over the last few years, sports news has been finding more and more minutes on television and radio. Similarly, sports news has been taking up more space in the written press, whether traditional or digital. This has been demanded by a citizenry with a great interest in knowing the results of each competition, but also the details of the process itself and of the sports management. In this line of specialization, however, the audience has not been reduced. On the contrary: it has been extended. In this sense, the consideration of sport as a mass phenomenon is undoubted (Moscoso-Sánchez, Fernández-Gavira \& Pérez-Flores, 2018). In this context, we must not forget the interest of media companies in controlling this type of information content (Sherwood \& Nicholson, 2017).

The phenomenon of sports reporting has influenced the emotional dimension of media content, especially the feeling of belonging (Birkner \& Nölleke, 2016; Kim, Magnusen \& Andrew, 2017). The use of the image has a direct relationship with that emotional dimension. For that reason, this work focuses on photography. In this context, there is no doubt that we are still immersed in the "civilization of the image" (Fulchignoni, 1964). For this reason, the visual and audio-visual media take on a special role in this process of constant influence. It is essential to work with these contents in order to bring them closer to the students, both in formal and non-formal education, promoting a critical vision and, above all, encouraging healthy habits. This is why it is so important to be critically aware of how sport is treated in the media. 
The content of these images should be reviewed from an educational and critical perspective. Therefore, this work focuses on a case study of the most prestigious festival of photojournalism from the international point of view, such as the World Press Photo ${ }^{1}$, a competition created in Amsterdam (The Netherlands) in 1955 by photographers themselves for the promotion of photojournalism. This organization currently has other educational and informative activities, such as workshops and exhibitions in different countries around the world. Among his awards, he has a speciality dedicated to sports photography. The finalist and award-winning photographs are, each year, photos that have had a great impact on the audience. In some cases, aesthetic or formal aspects stand emphasised. In a way compatible with this aspect, it is essential to make decisions in relation to the content represented.

In this line of work, the critical evaluation of the image and the attention to the contribution of the discursive aspects with the sense or meaning, social and always contextualized, establishes an interesting line of interdisciplinary contribution between educational and teaching fields. In this line of work, there is still a long way to go, such as the didactics of physical activity, sport and Health. All this is compatible with the use of these images in the context of Artistic Education and Media Education. Image analysis is one of the key actions to promote critical citizenship, whether in formal or non-formal learning contexts. The analysis of the image has been working in the educational-communicative activity for decades (Aparici \& García Matilla, 2008; Ferrés, 2014), also understanding that, together with this critical capacity, the creative dimension is fundamental (Aguaded-Gómez, 2012, p. 7).

When analysing informative images, it should be noted that, as it was done from the beginning, photography is considered a testimony, a social document (Freund, 1974/2001). However, since the invention of this medium, the risk of identifying an image with one's own reality has become evident (Benjamin, 1931/2011, p.52). In the midst of the post-truth era, it is important to bear in mind the image's consideration of creation or simulacrum, to use the terminology of Jean Baudrillard (1978/2005). Throughout more than a century of existence, reflection on this medium has offered some keys to its critical interpretation (Barthes, 1980/2004; Dubois, 1999; Sontag, 1961/2007), both in terms of content and form. In this line of critical thinking, we find the consideration of the image in the media as a distortion of reality, often intentional (Acaso, 2007, p.15) or, in its case, as the result of this assignment of veracity. The acceptance of the characteristics of the medium itself comes when we consider it not as truth but as appearance (Sánchez Montalbán, 2018, p.200). For this reason, this research, rather than studying the degree of fidelity with respect to the referent represented, focuses on defining the images that show the sport activity in the World Press Photo's list of winners.

Finally, following the most recent trends in the interpretation of the educational and communicative effects of the media, reference can be made to a true "industry of desire", which is how we can define true education today, as Joan Ferrés asserts (2008), but it is also how we can synthesize the new way of representing and approaching, from our screens, the reality of sporting activity. For this reason, the purpose of this work is to detail and explain the main keys in this process of representation of sport, evaluating the degree of distance from the reality of physical activity in this continuous process of representation, the value of the elite in the face of daily sport and accessible to citizens, as well as the possible links with issues resulting from the social responsibility of the press, such as Health care. In this sense, the idea of sport is defined by the imaginary of the photographs of events and sports news, of which the winners of a prestigious professional competition are a good example.

${ }^{1}$ The Wold Press Photo website is available at https://www.worldpressphoto.org (accessed 2 April 2018). 
Finally, it is necessary to take into account an added factor, which gives a special capacity for social penetration, such as the massive dissemination of sports images through digital media and mobile devices. In the middle of a process of media convergence and, specifically, in a permanent visual storytelling (Jenkins, 2003), where the creation of content is part of the online culture (Jenkins, Ford \& Green, 2015). The audience is no longer passive, but is made up of a presuming citizenry. This audience has the capacity to produce images on the Net, as Toffler defined prophetically at the end of the last century (1980), just as Jean Cloutier (1975) explained this horizontality of processes by using the term EMIREC as an activity that defined social participation.

In other words, we not only consume images of sport, but we create them as a first step to reproduce cultural patterns and patterns associated with physical activity. All this in a permanent process of hyper mediations (Scolari, 2008) in which the human dimension of the relational factor is very important (Marta-Lazo and Gabelas, 2016). In this context of work, in addition, either from the analysis of content, as is this research, or from the stimulus of visual creation, the enormous capacity to learn transversal contents that literacy and artistic and visual creation have, a key element for human development, is present (Eisner, 1991; Gardner, 1994). Therefore, there are many possibilities for integration into sports education. Sport and its image confront us to value what we really are and the design of what we would like to be. We are, without any doubt, facing an interesting possibility of working with the iconography of the 21 st century.

\section{MATERIAL AND METHODS}

\section{Methodological framework}

With the main objective of analysing the photographic representation of sport in the press, evaluating the main keys related to content and formal expression, as well as its educational possibilities, this work is based on the consideration of the works analysed as case studies, understanding that in this type of research it is important to understand the photographs studied, rather than considering them as representative of the entire universe of journalistic photography. In other words: the important thing is to understand the specific case you are working with (Stake, 2007, p.17). Studying specific photographs allows for an in-depth development of a fundamentally qualitative analysis, but also contemplates a basic quantification of certain variables, especially in the analysis of formal features that allow for catalogable identification. These can be the types of framing. It is a study, therefore, that is framed in the analysis of content (Bardin, 1986; Krippendorff, 1990), developing a structure and a process that attends, firstly, to formal or expressive questions, and secondly, to the very meaning and meaning that these discursive decisions make possible. In this line of work, the theoretical-practical paradigm of the Audio-visual Narrative is applied (García García, 2006; García Jiménez, 1993; Prósper Ribes, 2004). Special attention is paid to the differentiation between history and discourse, that is, between the what and the how (Chatman, 1978/1990).

This work also focuses on semiotic interpretation, following a consolidated line of research that considers it as one of the possible options (Marzal, 2004). The bases of image analysis and theory are taken into account (Mitchell, 2009; Villafañe \& Mínguez, 1996). The variables studied start from the focus on formal aspects, such as colour, light, form or texture, to continue with the study of the compositional strategy, with special attention to the presence of contrast or visual harmony, as well as the balance and distribution of visual weights. Finally, in this analysis, attention has been paid to the connection of these aesthetic elements with content and context, that is to say, with what could be considered as the substance of the expression Hjelmslev (1943/1971) or essence of the message, as well as its contextual and educational implications, although it is an eminently textual analysis, that is, focused on photographs that form part of the selected sample. 


\section{Sample justification and empirical framework}

As far as sample justification is concerned, the analysis has been limited to the World Press Photo Awards 2017. The reason is that the first criterion was the current one, assessing the real trend of photojournalism in the most recent time frame possible. In this way, the consideration of case studies, typical of Education, allows us to deepen, from a holistic perspective that takes into account multiple dimensions, the analysis of these photographs. Their selection is based on the selection criteria of quality, relevance, notoriety and prestige that implies having been awarded in the most prestigious international festival of photojournalism. In World Press Photo only graphic journalists participate. In particular, a total of 33 images have been studied, corresponding to the three individual image awards ("Singles") in the "Sports" category, in addition to the corresponding categories awarded as "Stories" in the same sports category. These last works are composed of 10 images presented by the candidates, linked as a story that reflects the human and social profile of sport.

In this way, a double narrative concept appears. On the one hand, the synchronous facet that involves evaluating a micro narration composed of 3 photographs as a report on the human dimension; on the other hand, the global nature of the images in this competition, that is to say, of its historical archive, whose analysis is proposed, in the discussion section, as a suggestion for future research, centred on all the images that the organisation has published on its website as a timeline. In fact, the competition itself, founded in Amsterdam (The Netherlands) by a group of photographers, makes reference in the presentation of its website to the importance of the visual narration of human history itself represented by the winning images since its foundation in 1955. In fact, in recent years it has been paying special attention to visual storytelling ${ }^{2}$, with a specific audio-visual category that has not been taken into account in this analysis, as it is focused exclusively on the visual aspect of the winning works.

In addition to its trajectory and prestige as a competition, different relevant activities are added, such as the setting up of a training department, exhibitions and identification of talents, with continuous educational projects and masterclasses, as well as a line of dissemination through the exhibition activity. The recognition of the sector is, for this research, the guarantee of being working with the most internationally renowned and influential photos, whose style sets a trend, every year, in contemporary photojournalism.

\section{RESULTS}

The analysis of the winning images of World Press Photo in 2017, corresponding to photographs taken in 2016, confirm the trend that connects the spectacular with the visual representation of sport, consolidating a photographic language focused on highlighting a decontextualized and unrealistic dimension of sport. This represents a risk in terms of promoting certain didactic contents from the point of view of teaching physical activity and health as positive aspects, something far removed from elite sport. This is particularly the case for the winning photos in the "single" category, while the creative strategy is different in the sequential integration of the winning photographic essays in the "stories" subcategory of sports photography. The recreation of a spectacular universe is a phenomenon that has been influenced, without a doubt, by the emergence of digital media and the technical possibilities they offer, despite the fact that it is an exercise in photographic realism with very restrictive possibilities of creation, that is, subject to many norms in order to participate in the competition. Throughout the presentation of the results, some of the variables of analysis are studied in depth, starting from the aesthetic aspect and ending in the general sense or meaning, as well as the context and the educational implications of this type of visual message.

2 Recovered from https://www.worldpressphoto.org/collection/contests/ (Date of consultation: 9/4/2018). 
Firstly, taking into account the formal and compositional aspects, the winning works demonstrate the importance of the use of colour as a strategy in the creation of images, so that in the three winning photographs in the sports modality (Figures 1 to 3 ) the value of this formal element as an expressive resource is clear, highlighting the sense of veracity and realism of the images, but also highlighting some tones with great intensity. All this, respecting the strict norms that do not allow manipulation of the colour, reflections, shadows nor, of course, adaptation or adjustment of the scene. However, despite meeting these requirements, the commitment to expressiveness goes beyond the exercise of faithful reproduction of formal characteristics or, at least, the selection of reality is precisely the one that offers the greatest degree of visual poetics, in photographs that have nuances of great importance in the final message and in their perception.

There are also no excessive possibilities to modify the light when capturing or processing the image in the competition. We work to the limit of these restrictions, but always with an unquestionable ethical application of the principles of photojournalism. The requirements of the photographs to be accepted in the competition are very strict with everything related to editing and post-production, allowing you to modify only basic parameters such as brightness, without scaling or changing the resolution. Of course, the content is not modified, except in the cleaning of any detail such as imperfections or dust spots on the display. However, given the difficulty of purity in the exercise of photojournalism, in many cases the reality itself is already represented by artificial light and a scenic arrangement that favours the chiaroscuro or excessively harsh light in interiors, as is the almost pictorial air of the photograph of tennis player Gael Monflis, taken by Cameron Spencer, in the second prize (Figure 2). This primacy of aesthetics reinforces the mythical tone that takes great sportsmen away from reality. It is also common to portray the situation, as is the case, in a pirouette that involves great difficulty. In the case of that photograph, the instant after the fall, it implied a small lesion.

The form, understood as an outline or figure, usually reinforces the contrast in a style of photography, which has characterized the image in the press, which has its origin, not so many decades ago, in the publication in black and white originally, which made an attempt to highlight, especially, the silhouette and recognition of the characters. Today, the interior of newspapers printed on paper is still black and white. In this sense, this line of work has been perfectly adapted to the new digital media, but it continues to focus on what the Escuela de la Gestalt called "pregnancies" as an ability to perceptively convey a clear, unequivocal form. The contrasted image, both in colour and form, is a common feature of the total number of images analysed.

In addition to colour, light and form, the treatment of textures is also important in images that reflect a variety of scenarios, not only colourful, but with multiple perceptive and corporeal texts, including the earth, the green, the moquettes, the track and the shine of sweat. It is, in general, the most clear and precise way to represent a reality with the possibilities of the media. Digital has exponentially improved the potential for "technical reproducibility" referred to a century ago by Walter Benjamin (1936/2003). It could be argued that the resolution may sometimes lead one to believe that we are dealing with an "excess of reality", overcoming one's own natural perception. This phenomenon is a great risk for digital journalistic photography.

There is a demonstration of professionalism on the part of the press photographer as a genre of visual creation, but always taking into account the priority of the content. For example, compliance with some standards such as the rule of the thirds is undoubted. In some cases, it is absolutely clear, like the image of the falling Jockey (Figure 1), just one of the points of force of the rule of thirds; or the smile of Usan Bold, in a picture of Kai Oliver Pfaffenbach becoming an icon (Figure 3). In this case, a whole exercise of playing with the shutter to stop the instant of a smile and perform a sweep of the grandstand, a common technique in the photographic coverage of motor competitions. 


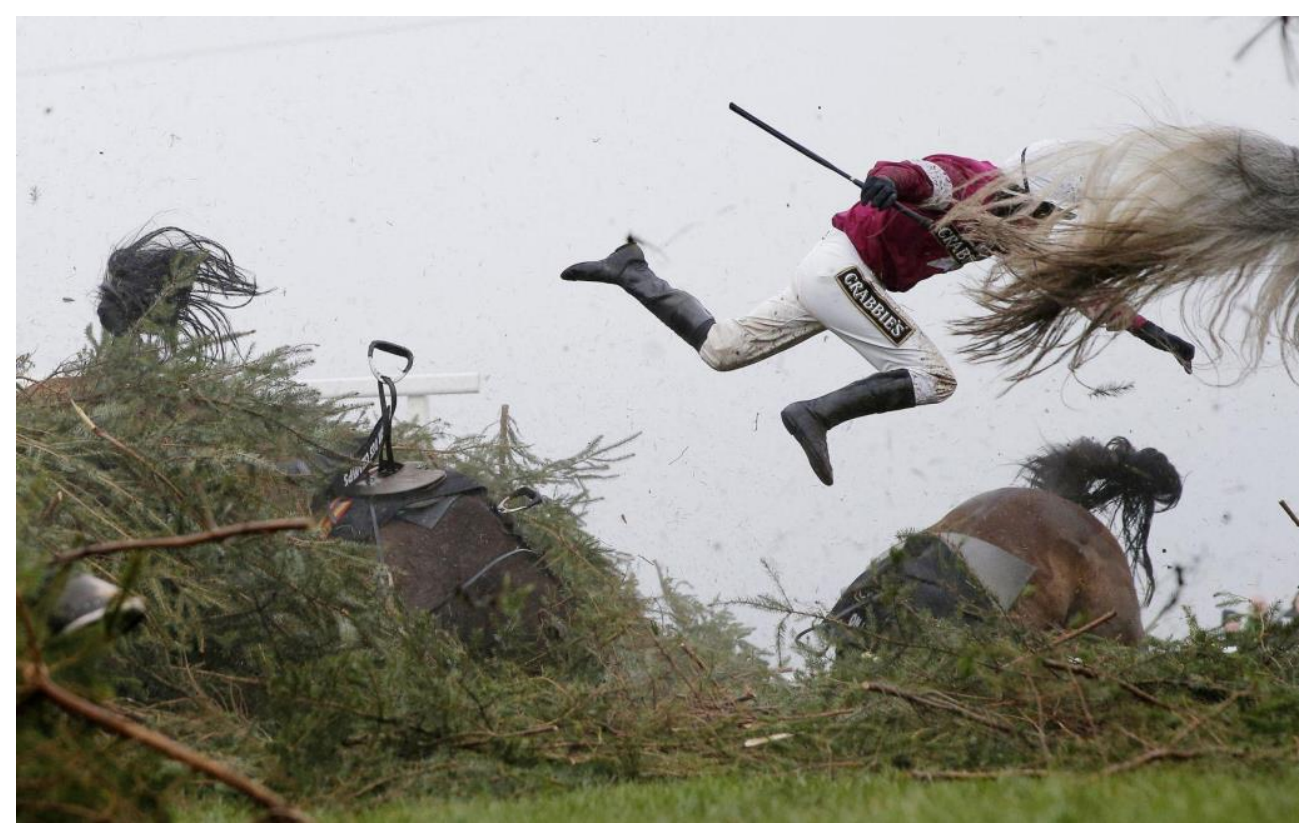

Figure 1. Jockey Nina Carberry "flies" from her falling horse at the National Obstacle Championship in Liverpool. 1st Prize in the Sports category of World Press Photo 2017. Published in The Guardian on April 9, 2016. Author: Tom Jenkins. Image retrieved from:

https://www.worldpressphoto.org/collection/photo/2017/sports/tom-jenkins (last accessed April, 4 2018).

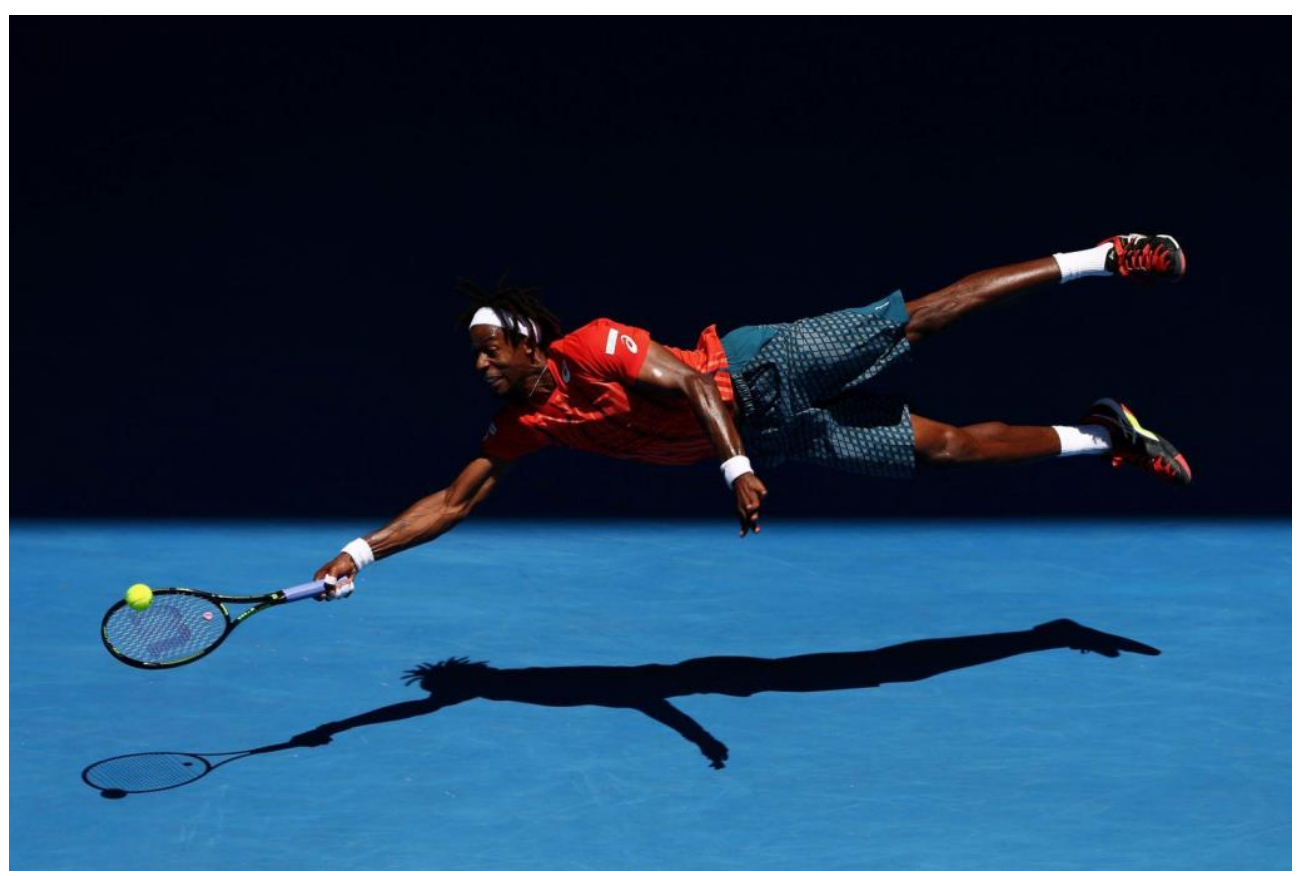

Figure 2. Gael Monflis at the Australian Open Tennis 2016, Melbourne, Australia. He was injured in the fall. 2nd Prize in the Sports category of World Press Photo 2017. Author: Cameron Spencer. Image retrieved from https://www.worldpressphoto.org/collection/photo/2017/sports/cameron-spencer (last accessed April, 9 2018). 


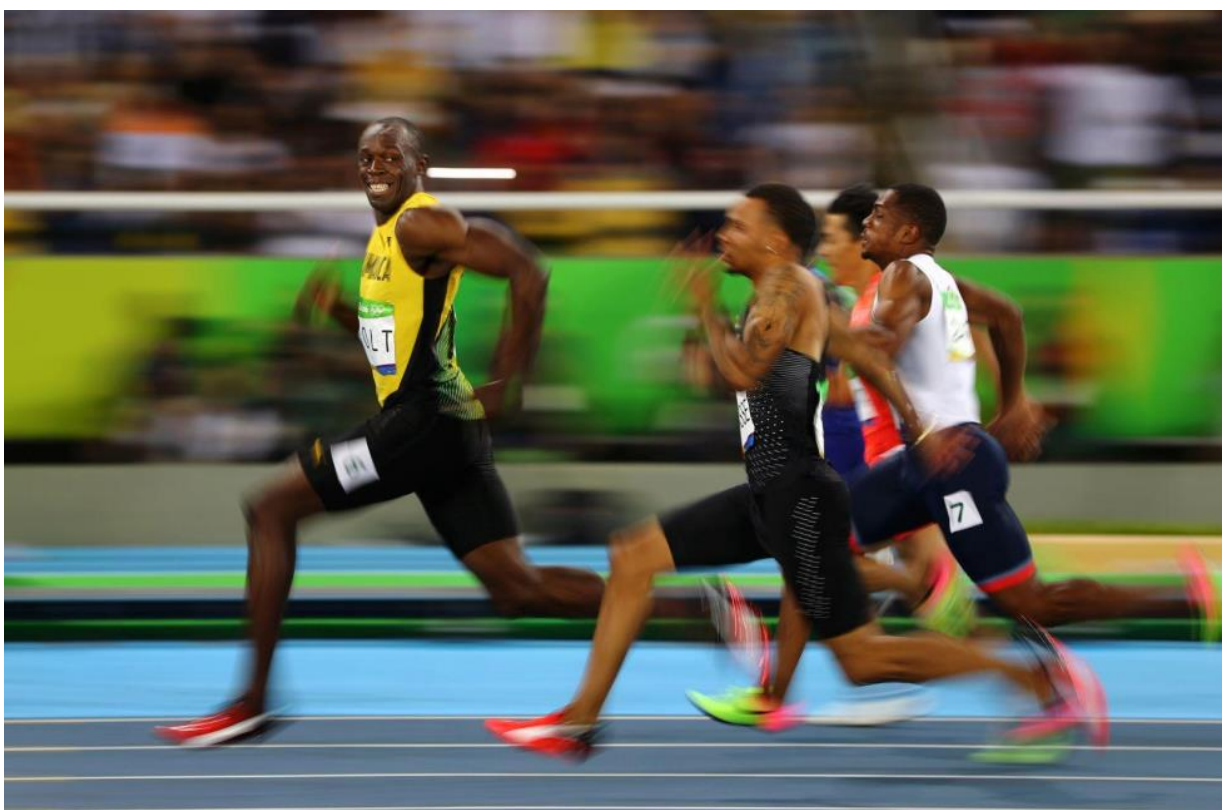

Figure 3. Usain Bolt in the $100 \mathrm{~m}$ semi-finals of the Olympic Games in Rio de Janeiro (Brazil). 3rd Prize in the Sports category of World Press Photo 2017. Author: Kai Oliver Pfaffenbach. Image retrieved from https://www.worldpressphoto.org/collection/photo/2017/sports/kai-oliver-pfaffenbach (last accessed April, 9 2018).

\section{Composition}

In the compositional strategy, in addition to contrast, which usually prevails over homogeneity or harmony. It is important to take care and to pay attention to the balance, with more or less dynamic tension, but always paying attention to clearly highlighting the centre of interest and to fulfil the proportions of the rule of the thirds. In other words, the compositional canon is fulfilled in the winning photos of the studied edition, in which we can always find coincidences with the strong points and the observance of the rule of the thirds, especially in the main photos of the "single" category, which must communicate effectively in a unique image.

In the "stories" modality, within sports, we observe some nuances typical of a work that does not have to translate, immediately and synchronously, all its significance and strength in a single image, but is based on the narration of 10 photographs as photo essays. It is not so important to get a definitive moment, but the value is the sum of the moments. For this reason, the aesthetic license of black and white, unimaginable for the search for a single cover photo in digital media, is complemented by the combination of a greater variety of compositional strategies, with more or less dynamic tension. Even, as in the case of figure 5 or much of figure 6, some prominent areas of the image that are characterized more by harmony than contrast, with a more common use of the wide angle. This way of working is directly related to the proportionality in the types of planes.

\section{Types of framing}

As shown in Figure 4, most of the photographs analysed cover the entire scene. This is a fairly common characteristic in photojournalism, since it responds to the intention to inform, as opposed to the aesthetic sense. All the general plans make up a total of $45 \%$ of the photographs analysed. Similarly, the mid-plane is also a support to provide information about the person. 


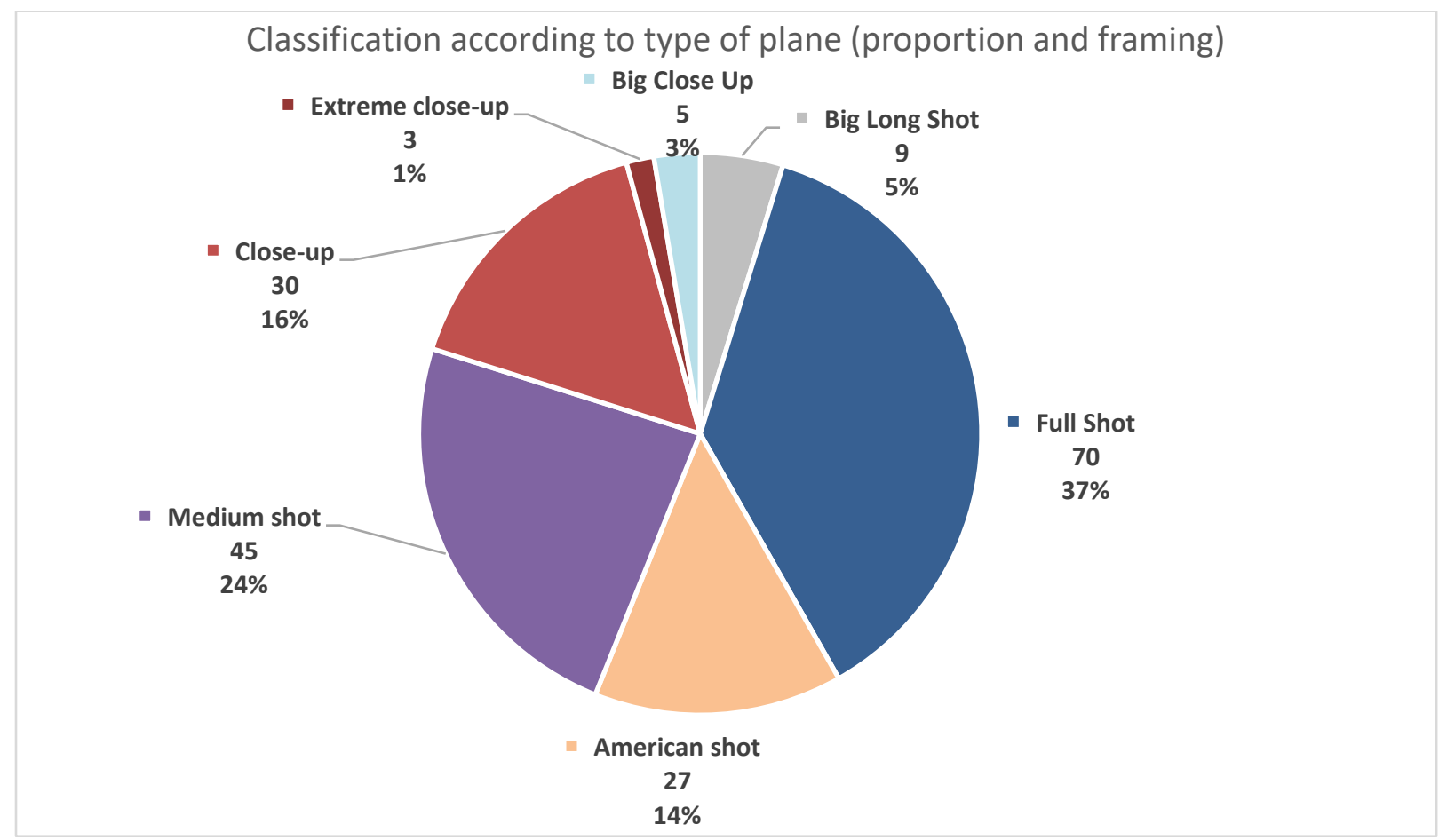

Figure 4. Types of framing

\section{Contents}

In any of the winning photos, there is no doubt that the human element is the central element, as is characteristic of the contemporary approach to news production, except in cases where the protagonism of buildings or infrastructures stands out, which is not usual in the winning images of the World Press Photo. In this sense, in the general category there is a focus on the main person and the action, while the three prizes in the "stories" category reflect a choral protagonism. Thus, while the photos of the sports category represent an individual dimension, the photo essays reflect a human aspect, more social and distant from the sense of the elite, in which a greater emotional dimension is offered, deepening the diversity of the identity of the sportsman's figure.

The treatment of black and white in Giovanni Capriotti's photographs (Figures 5 to 7 ) is remarkable. It is important to emphasize that, in the permanent action of narrating stories developed by professionals of photojournalism, storytelling or permanent narrative, typical of the convergence of media, is one of the main characteristics. It is a networked media model that, more than a great photo, demands the continuity of different visual moments to explain the same reality. In this sense, the "stories" modality is very successful. It shows the contrast between the personal side and a sport with a reputation for harshness, offering images of the Gay-Frienly Rugby Team from Toronto (Canada).

However, the visual homogeneity or the absence of contrast in any particular photo makes it difficult to highlight a focus of interest. There is a global perception in the visual essay. It is also a critical reflection of society. Furthermore, the topic associated with the logic of photographing sports as "stopped moments" with a high shutter speed is confirmed. The first prize in this category makes it very clear that the idea of the "decisive moment" by Henri Cartier Bresson (2014) will continue to exist in this genre of photography, as it did in the second and third prizes (Figures 6 and 7). As opposed to the narrative category, more typical of a report, it is about "photo news" that reflect a key moment in some important competition. 

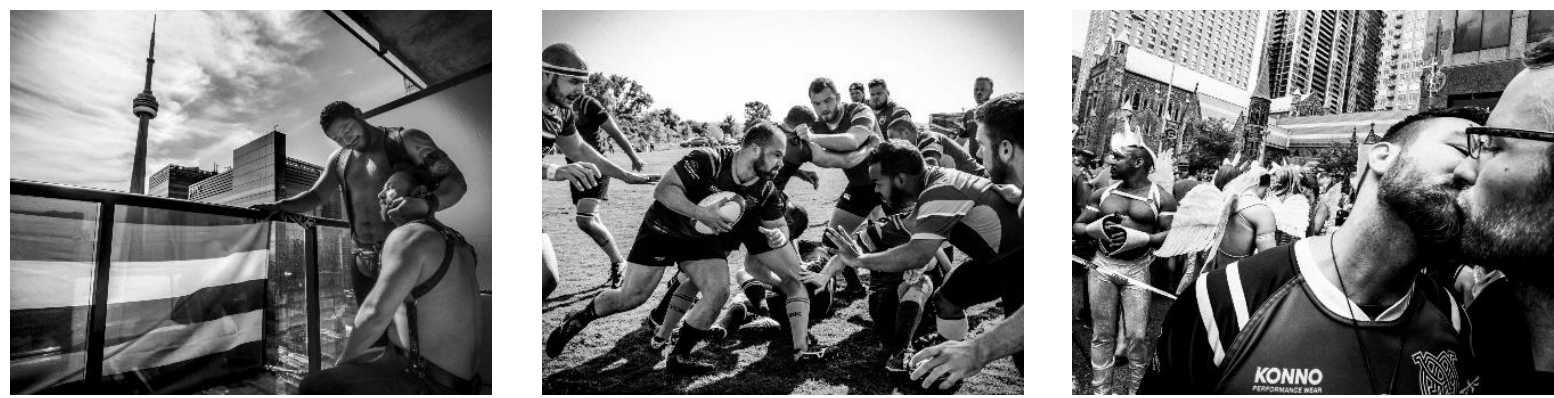

Figures 5 to 7.3 of the 10 photographs awarded in the Stories category, in the sports category, with the "Boys will be Boys" project, focusing on the Muddy York Rugby Football Club of Toronto (Canada). Author: Giovanni Capriotti. Images retrieved from:

https://www.worldpressphoto.org/collection/photo/2017/sports/giovanni-capriotti (last accessed April, 9 2018).

Among the values that are represented in these photographs, the three winning images of the sports modality focus on representing a single person. Individualism, therefore, is associated with success and personal improvement. However, the category "Stories" reflects a much more collective, social and emotional dimension. It covers content that also reflects a controversial question or a critical view of exclusion. The photos analysed are in fact two different working materials that offer great possibilities for didactic work. They allow us to teach not only questions of visual analysis, but also of the contextual location of the contents. In addition to dealing with a dimension that is more surprising in relation to the stereotypes of the gay world, the second and third prizes deal with questions such as competitiveness or access to training and fitness for a people with disabilities. It is a complement to a biased and partial view of the winning photos, which focus on a spectacular idea of the sport. In many cases, an idea far from reality. In others, a grand exercise in realism. It is true that, in the winning categories, the majority of sports are not given priority. The criterion is related to the impact of the image. However, of course, the news value of the image is a fundamental criterion. It is, therefore, a double vision, centred on the spectacular image, on the one hand, and on the critical and human dimension, on the other.

\section{DISCUSSION AND CONCLUSIONS}

In analysis, which has advanced from the formal aspects to the interpretation of meaning, it is only an initial approximation step to a set of images that offer a high educational potential, both in the study of aesthetic aspects and in the critical interpretation of meaning. This second aspect is very interesting from an educational point of view. However, as a discussion of the research itself, it is clear that there is a need to expand the sample and years of evolution in the analysis carried out. This may be a proposal for future research. It is important to focus the attention on the didactic work with this type of images, because of the real interest that it can generate in the students, generating impact both in its form and in its content. In addition, there are not many connections between Media Education and photojournalism, but much less in the study of physical education, which is a new aspect.

The main conclusion is the spectacularization of sports images. Quality and visual impact is a priority over the fact that it is an elite mass sport, although the newsworthy demands both aspects. In addition to the formal questions, it is important to note that these images are far removed from the real and daily context of the practice of Physical Education. There is a certain distance between these images, even in the treatment of the formal and compositional elements, with respect to the daily practice of sport by citizens. Icons are created and forged through the photographs published in the press. From an educational point of view, it is 
an opportunity to work on the teaching of body language and physical education, as well as the teaching of the visual arts. Always, in the common and interdisciplinary field of Media Education. In this sense, it can be observed that the category "stories" offers a much more interesting human dimension for the transversal work of Education in Values.

Aesthetics, technique and content logic are three completely indivisible aspects in the photographic representation of sport that is published daily in the media. The culture of the event, with an emphasis on elite sport, occupies a space that could be devoted to other more didactic and useful approaches for citizens, such as physical exercise linked to Health care. The use of the visual media dimension to reinforce the critical capacity of the citizens and, in addition, to work from the transversality the value of the sport activity. The images analysed address, in the category of photo essays, more social issues, which are designed from a critical point of view, denouncing values such as competitiveness or stimulating the positive vision offered by social inclusion, related to the disability handicap. Sport has all these faces.

Finally, it must be said that health is not directly addressed in these images. Sport is linked to competition in the main category. However, values such as individual effort, self-improvement, etc. are present. Finally, it is important to remember the need to design and implement educational and research actions that focus critically on the media's imaginary of sport. Its enormous social influence justifies the need to work with these contents at any level of the education system.

\section{REFERENCES}

Aguaded-Gómez, J.I. (2012). La competencia mediática, una acción educativa inaplazable. Comunicar, 20(39), 7-8. https://doi.org/10.3916/C39-2012-01-01

Aparici, R. y García Matilla, A. (2008). Lectura de imágenes en la era digital. Madrid: Ediciones de la Torre.

Bardin, L. (1986). Análisis de contenido (C. Suárez, trad.). Madrid: Akal.

Barthes, R. (2004). La cámara lúcida: Nota sobre la fotografía (J. Sala-Sanahuja, trad.). Barcelona: Paidós (1st ed. 1980).

Barthes, R. (2008). Del deporte y los hombres (N. Petit Fontseré, trad). Barcelona: Paidós.

Baudrillard, J. (2005). Cultura y simulacro (A. Vicens y P. Rovira, trads.). Barcelona: kairós (1st ed. 1978).

Benjamin, W. (2003). La obra de arte en la época de su reproductibilidad técnica (A. E. Weikert). México: İ́aca. (1st ed. 1936).

Benjamin, W. (2011). Breve historia de la fotografía (W. Erger, trad.). Madrid: Casimiro Libros. (1st ed. 1931).

Birkner, T., \& Nölleke, D. (2016). Soccer players and their media-related behavior: A contribution on the mediatization of sports. Communication and Sport, 4(4), 367-384. https://doi.org/10.1177/2167479515588719

Cartier-Bresson, H. (2014). Ver es un todo: Entrevistas y conversaciones 1951-1998 (C. Roche, trad.). Barcelona: Gustavo Gili.

Chatman, S. (1990). Historia y discurso. La estructura narrativa en la novela y en el cine. (M.J. Fernández Prieto, trad.). Madrid: Taurus. (Obra original publicada en 1978).

Cloutier, J. (1975). L'Ere d'EMEREC ou la communication audio-scripto-visuelle. Montreal (Canadá): Les Presses de l'Université de Montreal.

Dubois, Ph. (1999). El acto fotográfico: De la Representación a la Recepción (G. Baravalle, trad.). Barcelona: Paidós. (1st ed. 1983). 
Eisner, E.W. (1991). Educar la visión artística (D. Cifuentes Camacho, trad.). Barcelona: Paidós. (1st ed. 1972).

Ferrés, J. (1994). Televisión y Educación. Madrid: Akal.

Ferrés, J. (2008). La educación como industria del deseo. Un nuevo estilo comunicativo. Barcelona: Gedisa.

Freund, G. (2001). La fotografía como documento social (J. Elias, trad.). Barcelona: Gustavo Gili. (1st ed. 1974).

Fulchignoni, E. (1964). La moderna civiltà dell'immagine. Roma: A. Armando.

García García, F. (coord.). (2006). Narrativa Audiovisual. Madrid: Laberinto.

García Jiménez, J. (1993). Narrativa Audiovisual. Madrid: Cátedra.

Gardner, H. (1994). Educación artística y desarrollo humano (F. Meler-Orti, trad.). Barcelona: Paidós.

Hjelmslev, L. (1971). Prolegómenos a la teoría del lenguaje (J.L. Díaz de Liaño, trad.). Madrid: Gredos (1st ed. 1943).

Herrero Aguado, C. (2013). Periodismo Económico. La economía como eje vertebrador de la actualidad. In M. Sobrados León (coord.), Presente y futuro en el Periodismo Especializado (pp. 13-50). Madrid: Fragua.

Jenkins, H. (2003, January 15). Transmediastorytelling. MIT Tecnhology Review [online]. Retrieved from https://goo.gl/quFEh6

Jenkins, H., Ford, S. y Green, J. (2015). Cultura Transmedia: La creación de contenido y valor en una cultura en red (X. Gaillard Pla, trad.). Madrid: Gedisa.

Kim, S., Magnusen, M. \& Andrew, D. (2017). Sport team culture: investigating how vertical and horizontal communication influence citizenship behaviors via organizational commitment. International Journal of Sport Psychology, 48(4), 398-418. https://doi.org/10.7352/IJSP.2017.48.398

Krippendorff, K. (1990). Metodología de análisis de contenido. Teoría y práctica (L. Wolfson, trad.). Barcelona: Paidós.

Llano, R. (2008). La especialización periodística. Madrid: Tecnos.

Marta-Lazo, C. y Gabelas, J.A. (2016). Comunicación digital. Un modelo basado en el Factor R-elacional. Barcelona: UOC.

Martínez Rodríguez, L. \& Parra Pujante, A. (2010). Periodismo Especializado: Teoría y Práctica de la Especialización informativa. Universidad de Murcia.

Marzal Felici, J. (2010). Cómo se comenta una fotografía. Interpretaciones de la mirada ( $3^{\mathrm{a}}$ ed.). Madrid: Cátedra.

Mitchell, W.J.T. (2009). Teoría de la imagen. Ensayos sobre representación verbal y visual (Y. Hernández Velázquez, trad.). Madrid: Akal. (1st ed. 1994).

Moscoso-Sánchez, D., Fernández-Gavira, J., \& Pérez-Flores, A. (2018). The media construction of the sports' elite from the European perspective: an analysis of the European Symposium of Sports 2010. Sport in Society, 21(3), 516-528. https://doi.org/10.1080/17430437.2017.1346624

Prósper Ribes, J. (2004). Elementos constitutivos del relato cinematográfico. Valencia: Universidad Politécnica de Valencia.

Sánchez Montalbán, F.J. (2018). Fotografía de prensa. Del simulacro a la posverdad en la era digital. Index.comunicación, 8(1), 197-224. Retrieved from https://goo.gl/XJzmS1

Scolari, C. (2008). Hipermediaciones: Elementos para una Teoría de la Comunicación Digital Interactiva. Barcelona: Gedisa.

Sherwood, M., \& Nicholson, M. (2017). Who controls sport news? Media relations and information subsidies in Australian sport media. Media International Australia, 165(1), 146-156. https://doi.org/10.1177/1329878X17713340 
Sontag, S. (2007). Contra la interpretación y otros ensayos. Barcelona: Random Hause Mondadori. (1a ed. 1961).

Stake, R.E (2007). Investigación con estudio de casos (R. Filella, trad). Madrid: Ediciones Morata. (1 ${ }^{a}$ ed. 1995).

Toffler, A. (1980). La tercera ola (A. Martín, trad.). Barcelona: Plaza \& Janés.

Villafañe, J. y Mínguez, N. (1996). Principios de Teoría General de la Imagen. Madrid: Pirámide. 